\title{
Efficient Solar Water Splitting Photocathodes Comprising a Copper Oxide Heterostructure Protected by a Thin Carbon Layer
}

\author{
Pramod Patil Kunturu and Jurriaan Huskens*๑ \\ Molecular NanoFabrication group, MESA+ Institute for Nanotechnology, University of Twente, P.O. Box 217, 7500 AE Enschede, \\ The Netherlands
}

\section{Supporting Information}

ABSTRACT: Photoelectrochemical (PEC) solar water splitting has received extensive attention because it promises to provide an alternative and sustainable source of energy. A key challenge is to achieve a stable PEC system in either acidic or basic electrolyte without degradation of the (photo)electrodes. We have used a cubic $\mathrm{Cu}_{2} \mathrm{O}$ film and porous granular bilayer $\mathrm{Cu}_{2} \mathrm{O} / \mathrm{CuO}$ composite with a carbon protection layer as photocathode materials. The films were deposited under different conditions, such as variation of the electrodeposition time, thermal oxidation of the $\mathrm{Cu}_{2} \mathrm{O}$ films in air versus nitrogen atmosphere, and deposition of the carbon materials, and were investigated structurally and with regard to their PEC performance. The optimized electrodes showed photocurrents up to 6.5 and $7.5 \mathrm{~mA} / \mathrm{cm}^{-2}$ at potentials of 0 and $-0.1 \mathrm{~V}$ vs RHE at $\mathrm{pH} 5.5$, respectively. The stabilities of the $\mathrm{Cu}_{2} \mathrm{O} / \mathrm{C}$ and $\mathrm{Cu}_{2} \mathrm{O} / \mathrm{CuO} / \mathrm{C}$ photocathodes, at a low bias of $0.3 \mathrm{~V}$ vs RHE, were retained after $50 \mathrm{~h}$. The strongly improved photostability of the photocathodes in comparison to electrodes in the absence of a carbon overlayer is attributed to a more effective charge transfer and a protective role of carbon against photocorrosion.

KEYWORDS: copper oxides, bilayer composite, photocathode, carbon layer, solar water splitting

\section{INTRODUCTION}

The process of utilizing solar energy to produce hydrogen from water has gained increased attention to find ecologically benign alternative energy sources. ${ }^{1}$ Hydrogen is considered a nextgeneration fuel, ${ }^{2-6}$ yet presently it is produced primarily from burning fossil fuels. ${ }^{7}$ To make the process sustainable, hydrogen will need to be produced using renewable energy sources such as sunlight. ${ }^{8-10}$

In developing economical, large-scale solar-to-hydrogen technologies, photoelectrochemical (PEC) cells that use earth-abundant materials have received increased attention. ${ }^{11,12}$ However, long-term stability of these materials under PEC process conditions is an important issue. ${ }^{13-18}$ Among the photocathode materials used in PEC water splitting devices, cuprous and cupric oxides $\left(\mathrm{Cu}_{2} \mathrm{O}\right.$ and $\left.\mathrm{CuO}\right)$ fulfill many requirements, of which the band gaps, their ease of fabrication, and relatively low cost are the most important. The (direct) band gap of $\mathrm{Cu}_{2} \mathrm{O}(2.0 \mathrm{eV})$ has been calculated to provide a photocurrent of up to $14.7 \mathrm{~mA} / \mathrm{cm}^{2}$ with a solar cell efficiency of $\max 20 \% .{ }^{19-23}$ Minami et al. ${ }^{24}$ and Wong et al. ${ }^{25}$ have achieved efficiencies of $8 \%$ and $6 \%$ using devices with $\mathrm{Zn}_{1-x} \mathrm{Ge}_{x-} \mathrm{O}$ and $\mathrm{Al}_{x} \mathrm{Ga}_{1-x} \mathrm{O}$ multicomponent oxide thin films with $\mathrm{Cu}_{2} \mathrm{O}$-based heterojunction solar cells, respectively. These multicomponent oxides act as n-type oxide thin-film window layers, having smaller conduction band offsets (arising from a difference in electron affinity between the $\mathrm{p}-\mathrm{Cu}_{2} \mathrm{O}$ and the $\mathrm{n}$ - type semiconductor). This smaller conduction band offset leads to a higher device efficiency.

$\mathrm{Cu}_{2} \mathrm{O}$ and $\mathrm{CuO}$ have favorable and direct band gaps of approximately $2.0-2.6 \mathrm{eV}$ and $1.3-1.6 \mathrm{eV}$, respectively, depending on the synthetic methods and morphology of the nanomaterials. ${ }^{22,26-32}$ Although copper oxides absorb a vast portion of the solar spectrum, some key challenges prohibit the formation of highly efficient and robust photocathodes. ${ }^{33,34}$ One of the main issues in using copper oxides as a photocathode is a relatively strong electron-hole pair recombination, leading to a short diffusion length of the minority charge carrier. This diffusion length ranges from approximately $20-200 \mathrm{~nm}$ depending on the synthesis process, while the film must typically be at least $1 \mu \mathrm{m}$ thick to absorb most of the sunlight. It is therefore clear that efficient separation of the photoexcited electron-hole pairs is crucial. Thus, layer-by-layer fabrication and band bending strategies are used with suitable composite materials to achieve efficient copper oxide photocathodes. ${ }^{30,31,35}$ Another issue is the photostability in aqueous electrolytes; photocorrosion of copper oxides may occur because the redox potentials for their reduction and oxidation are positioned between the water

Received: June 28, 2019

Accepted: October 30, 2019

Published: October 30, 2019 
splitting potentials. ${ }^{36-38}$ Although numerous research efforts have been aimed at improved charge carrier collection at the photocathode by doping, ${ }^{39}$ decorating with cocatalysts, and nanostructure engineering, ${ }^{40,41}$ the photostability remains an issue for this material. ${ }^{29,30,42-46}$

$\mathrm{Cu}_{2} \mathrm{O} / \mathrm{CuO}$ heterojunction structures can be fabricated by facile methods, and these methods typically bestow the materials with high surface areas and good charge transport and conductivity. These properties make them suited as photocathode materials. Recently, studies by Diao et al. ${ }^{31}$ and Hwang et al. ${ }^{30}$ found that $\mathrm{Cu}_{2} \mathrm{O} / \mathrm{CuO}$ heterojunctions facilitate the photogenerated electron-hole separation and improve the charge transfer efficiency. At the same time, these studies showed a limited stability caused by photocorrosion in the electrolyte solution. To combat photocorrosion, Grätzel et al. ${ }^{47,48}$ prepared a $\mathrm{Cu}_{2} \mathrm{O} / \mathrm{Ga}_{2} \mathrm{O}_{3}$-buried $\mathrm{p}-\mathrm{n}$ junction with multiple protection layers made by atomic layer deposition (ALD). Photocurrents up to $10 \mathrm{~mA} \mathrm{~cm} \mathrm{~cm}^{-2}$ have been reported (at $0 \mathrm{~V}$ vs RHE). After coupling a noble metal electrocatalyst with a $\mathrm{RuO}_{2}$ cocatalyst, a stable operation was enabled exceeding $100 \mathrm{~h}$. However, the perspective for large-scale PEC application of this approach may be restricted because of the rather complex and costly fabrication process and the limited natural abundance of $\mathrm{Ru}$ and $\mathrm{Pt}$.

Thus, it is of high importance to develop alternative methods and to improve strategies to provide a scalable, facile, low-cost, and environmentally friendly method to manufacture a coating-layer-protected and thus highly stable photocathode for extended operation of $\mathrm{Cu}_{2} \mathrm{O} / \mathrm{CuO}$ in aqueous electrolytes. The chemical stability of the photocathodes may be improved by post-coating the $\mathrm{Cu}_{2} \mathrm{O} / \mathrm{CuO}$ heterostructures with thin protection layers of highly capacitive materials. Deposition of ultrathin amorphous and porous carbon, ${ }^{49,50}$ graphene, ${ }^{28,51}$ reduced graphene oxide, ${ }^{52}$ and graphitic carbon nitride nanosheets ${ }^{53}$ on $\mathrm{Cu}_{2} \mathrm{O}$ films have been reported recently to provide good electronic properties and improved chemical stability. In particular, coating $\mathrm{Cu}_{2} \mathrm{O} / \mathrm{CuO}$ heterostructures with a thin layer of carbon is beneficial owing to its high surface area, its high capacitive properties, and its nontoxic nature. Yet, utilization of expensive techniques, like CVD and high temperature pyrolysis, might limit its widespread applicability. ${ }^{54-56}$

In this work, we focus on the synthesis of cubic $\mathrm{Cu}_{2} \mathrm{O}$ films and porous granular bilayer composite $\mathrm{Cu}_{2} \mathrm{O} / \mathrm{CuO}$ heterostructure photocathodes, prepared by electrodeposition on FTO followed by thermal oxidation. The roles of electrodeposition time and atmosphere during thermal oxidation were investigated. To promote charge carrier collection and address the limited stability and photocorrosion, we prepared $\mathrm{Cu}_{2} \mathrm{O}$ / $\mathrm{CuO} / \mathrm{C}$ heterostructure photocathodes, in which the carbon thin layer is deposited in a "green", surfactant-free, deposition process using an aqueous glucose solution as a carbon precursor. Next to thorough PEC performance measurements, a systematic pre- and post-characterization of the heterostructured photocathode is provided with respect to the stability of the photocathodes.

\section{RESULTS AND DISCUSSION}

The fabrication of thin carbon layer-protected $\mathrm{Cu}_{2} \mathrm{O} / \mathrm{CuO}$ heterojunction photocathodes is shown in Scheme 1. The deposition of $\mathrm{Cu}_{2} \mathrm{O}$ on fluorine-doped tin oxide (FTO)covered glass substrates was achieved by electrodeposition using a lactate-stabilized copper sulfate solution, as reported
Scheme 1. Photocathode Fabrication Process of Glass/ FTO $/ \mathrm{Cu}_{x} \mathrm{O} /$ Carbon $^{a}$

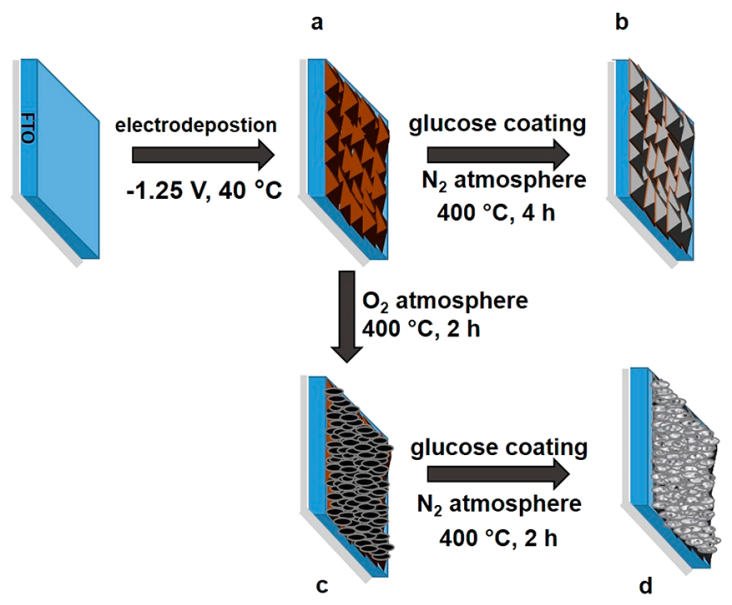

a(a) Electrodeposition of a $\mathrm{Cu}_{2} \mathrm{O}$ film on an FTO-covered glass substrate, (b) carbon deposition by aqueous solution coating of glucose followed by thermal annealing in $\mathrm{N}_{2}$ atmosphere, (c) heterostructure formation by thermal annealing of $\mathrm{Cu}_{2} \mathrm{O}$ film in $\mathrm{O}_{2}$ atmosphere, and (d) carbon deposition by solution coating of glucose followed by thermal annealing in $\mathrm{N}_{2}$ atmosphere.

previously. ${ }^{57}$ Throughout the electrodeposition of $\mathrm{Cu}_{2} \mathrm{O}$, performed at a constant cathodic potential of $-1.25 \mathrm{~V}$ at varying deposition times, an even and uniform yellowishorange layer formed on the FTO substrate. The samples were subsequently subjected to heat treatment at $400{ }^{\circ} \mathrm{C}$ for $1 \mathrm{~h}$ in $\mathrm{O}_{2}$ atmosphere, upon which the formation of $\mathrm{Cu}_{2} \mathrm{O} / \mathrm{CuO}$ heterostructures was observed (analysis discussed below). Subsequently, a solution-based glucose coating of the bare $\mathrm{Cu}_{2} \mathrm{O}$ films and of the $\mathrm{Cu}_{2} \mathrm{O} / \mathrm{CuO}$ heterostructures was applied, followed by annealing of the samples under $\mathrm{N}_{2}$ environment to form the carbon film as a protective layer (Scheme $1 \mathrm{~b}$ and $\mathrm{d}$ ).

Figure $1 \mathrm{a}-\mathrm{c}$ shows the morphology of $\mathrm{Cu}_{2} \mathrm{O}$ films that were synthesized by variation of the electrodeposition time (1000 to $6000 \mathrm{~s}$ ) at constant cathodic potential. Clearly, a time of $1000 \mathrm{~s}$ was insufficient to achieve full coverage, but uniform and compact films with film thicknesses of 1.8 and $3.2 \mu \mathrm{m}$ were obtained at deposition times of 3000 and $6000 \mathrm{~s}$, respectively. At the applied deposition potential $(-1.25 \mathrm{~V})$, the $\mathrm{Cu}^{2+}$ ions present in the electrodeposition solution usually precipitate into $\mathrm{Cu}_{2} \mathrm{O}$ while $\mathrm{Cu}$ codeposition is suppressed. ${ }^{19,58}$ Initially, nuclei of $\mathrm{Cu}_{2} \mathrm{O}$ are formed on the bare FTO substrate when applying a comparatively high cathodic current density. Upon reaching a certain surface density of the nuclei, this layer promotes further growth, and the current density decreased to reach a plateau after approximately $1000 \mathrm{~s}$ (Figure S1). ${ }^{59}$ Depletion of the electrolyte from metal ions close the electrode surface is thought to be the reason for the initial decrease of the cathodic current density, while the plateau observed later is attributed to cuprous oxide formation. ${ }^{60}$ First, small grains nucleated on the substrate surface to form cubic islands as shown in Figure S2. As the deposition time increased, a specific preferred orientation developed to present a texture first with isolated (Figure 1a) and later with interconnected (Figure 1b, c) cubes. The specific preferred orientation was observed by Askimoto and co-workers, ${ }^{61}$ who showed that the crystallographic orientation is important to reduce the optical reflection 

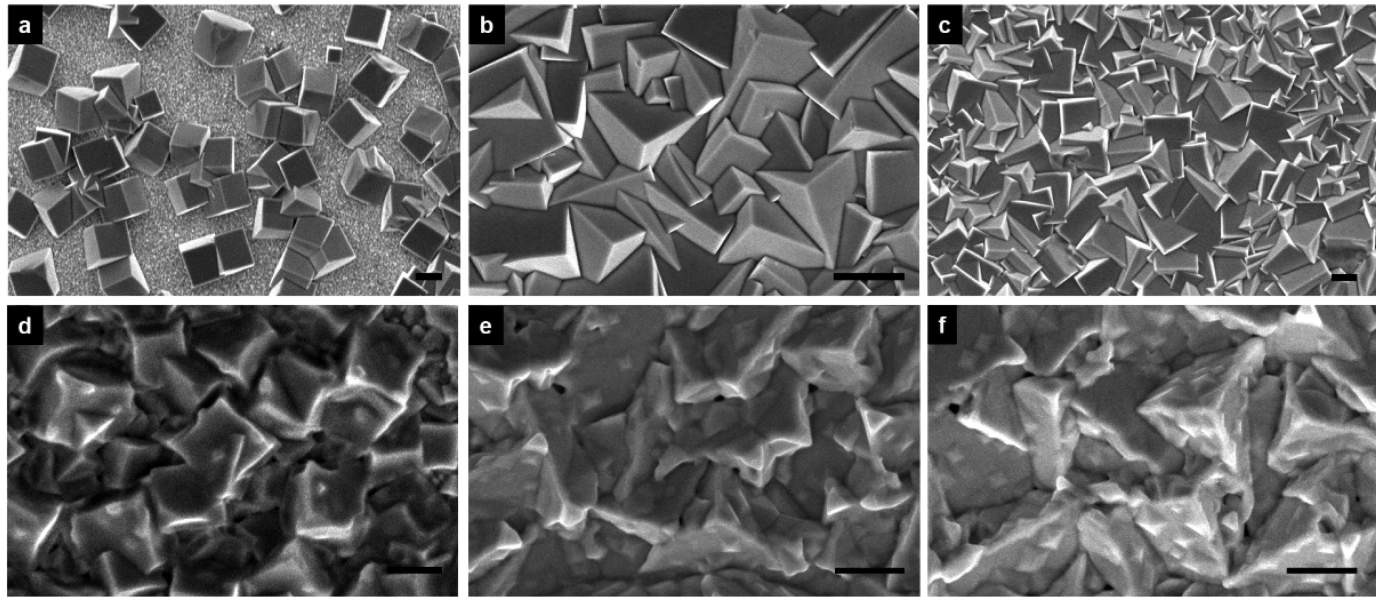

Figure 1. SEM images of electrodeposited $\mathrm{Cu}_{2} \mathrm{O}$ films on FTO substrates with various electrodeposition times: (a) $1000 \mathrm{~s}$, (b) $3000 \mathrm{~s}$, and (c) $6000 \mathrm{~s}$, and $(\mathrm{d}-\mathrm{f})$ the corresponding carbon-coated $\mathrm{Cu}_{2} \mathrm{O}$ films prepared by subsequent glucose deposition $(3 \mathrm{mg} / \mathrm{mL}$ in water $)$ and annealing. Scale bars represent $1 \mu \mathrm{m}$.
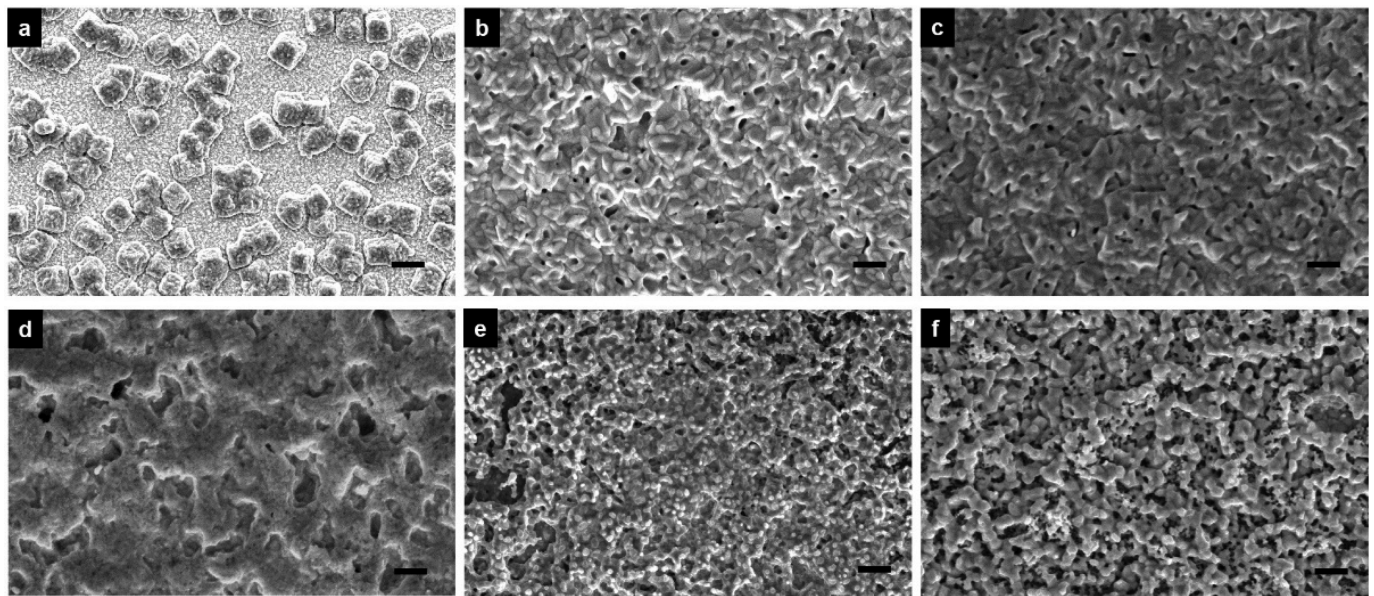

Figure 2. SEM images of $\mathrm{Cu}_{2} \mathrm{O} / \mathrm{CuO}$ heterostructure films on FTO substrate, made by electrodeposition, at various electrodeposition times of (a) $1000 \mathrm{~s}$, (b) $3000 \mathrm{~s}$, and (c) $6000 \mathrm{~s}$, followed by annealing in $\mathrm{O}_{2}$ atmosphere, and $(\mathrm{d}-\mathrm{f})$ the corresponding carbon-coated $\mathrm{Cu}_{2} \mathrm{O} / \mathrm{CuO}$ films prepared by subsequent glucose deposition $(3 \mathrm{mg} / \mathrm{mL}$ in water) and annealing. Scale bars represent $1 \mu \mathrm{m}$.

resulting in improved performance in electrical rectification and photosensitivity. ${ }^{62}$

The as-electrodeposited $\mathrm{Cu}_{2} \mathrm{O}$ films were subsequently exposed to heat treatment at $400{ }^{\circ} \mathrm{C}$ in $\mathrm{O}_{2}$ atmosphere for 1 $\mathrm{h}$, thus leading to the formation of a $\mathrm{CuO}$ layer on top of the $\mathrm{Cu}_{2} \mathrm{O}$ film to form a $\mathrm{Cu}_{2} \mathrm{O} / \mathrm{CuO}$ heterojunction. As shown in Figure $2(\mathrm{a}-\mathrm{c})$ the top-view morphology of the original $\mathrm{Cu}_{2} \mathrm{O}$ film was changed after the thermal oxidation step, resulting in a more granular and porous morphology. These observations are in line with conclusions reached in earlier studies, which have shown that the $\mathrm{Cu}_{2} \mathrm{O}$ film is oxidized to $\mathrm{CuO}$ from the outside inward, thus creating a $\mathrm{Cu}_{2} \mathrm{O} / \mathrm{CuO}$ heterojunction. Upon extensive oxidation, only $\mathrm{CuO}$ remains. ${ }^{47,63}$ Similarly, in our work, the thickness of the $\mathrm{Cu}_{2} \mathrm{O}$ and the $\mathrm{CuO}$ layers in the heterostructure was a function of the oxidation time. When the temperature was set at $400{ }^{\circ} \mathrm{C}$ for $1 \mathrm{~h}$, the sample consisted of two layers as shown in Figure S3b, where the top layer is $\mathrm{CuO}$ that lies on top of the remaining $\mathrm{Cu}_{2} \mathrm{O}$. When the thermal oxidation time was increased to $3 \mathrm{~h}$, the film of $\mathrm{Cu}_{2} \mathrm{O}$ was oxidized completely, and the material was turned fully into porous $\mathrm{CuO}$ as shown in Figure S3c. These results confirm that the layer thickness ratio of $\mathrm{CuO}$ and $\mathrm{Cu}_{2} \mathrm{O}$ can be tuned by variation of the thermal oxidation time.

The electrodeposited $\mathrm{Cu}_{2} \mathrm{O}$ thin films and $\mathrm{Cu}_{2} \mathrm{O} / \mathrm{CuO}$ heterostructures were immersed in a glucose solution $(3 \mathrm{mg} /$ $\mathrm{mL}$ ) and dried at ambient conditions to remove the solvent. Then, the samples were annealed at $400{ }^{\circ} \mathrm{C}$ in $\mathrm{N}_{2}$ environment for $2 \mathrm{~h}$ to form carbon-coated copper oxide heterostructures. During the initial phase of the annealing, the glucose is expected to dehydrate, by which covalent cross-links are formed, followed by the formation of aromatic functionalities and subsequent carbonization. ${ }^{36,49}$ Figures $1(\mathrm{~d}-\mathrm{f})$ and $2(\mathrm{~d}-$ f) show the carbon-coated $\mathrm{Cu}_{2} \mathrm{O}$ thin films and $\mathrm{Cu}_{2} \mathrm{O} / \mathrm{CuO}$ heterostructures, respectively, after deposition and annealing of the carbon layer.

Figure 3 depicts high-resolution transmission electron microscopy (HR-TEM) pictures and the corresponding energy-dispersive $\mathrm{X}$-ray spectroscopy (EDX) images for a single $\mathrm{Cu}_{2} \mathrm{O}$ crystal covered with a thin carbon layer. The HRTEM images (Figure 3a, c) of carbon-protected $\mathrm{Cu}_{2} \mathrm{O}$ and $\mathrm{Cu}_{2} \mathrm{O} / \mathrm{CuO}$ show clearly the $15 \mathrm{~nm}$ thick carbon layer covering the surface of the $\mathrm{Cu}_{2} \mathrm{O}$ and $\mathrm{Cu}_{2} \mathrm{O} / \mathrm{CuO}$ heterostructures. EDX (Figure 3b, d) and high-angle annular dark 

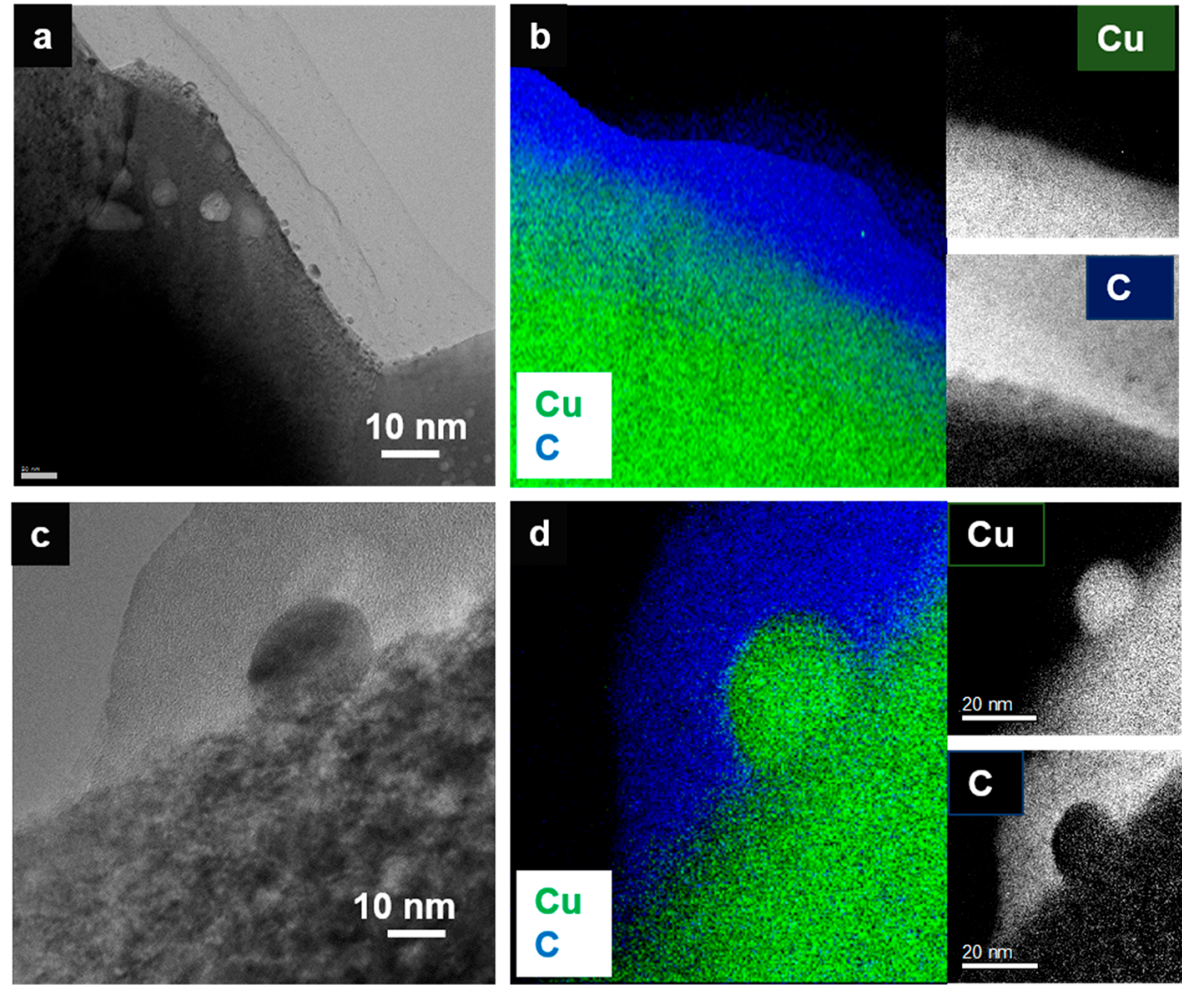

Figure 3. TEM and EDX characterization of the $\mathrm{Cu}_{2} \mathrm{O} / \mathrm{C}(\mathrm{a}, \mathrm{b})$ and $\mathrm{Cu}_{2} \mathrm{O} / \mathrm{CuO} / \mathrm{C}(\mathrm{c}, \mathrm{d})$ heterostructures (electrodeposition time $3000 \mathrm{~s}$ and concentration of glucose solution is $3 \mathrm{mg} / \mathrm{mL}$ ). (a, c) TEM cross section view and (b, d) combined elemental mapping with element mapping of $\mathrm{Cu}$ and $\mathrm{C}$.
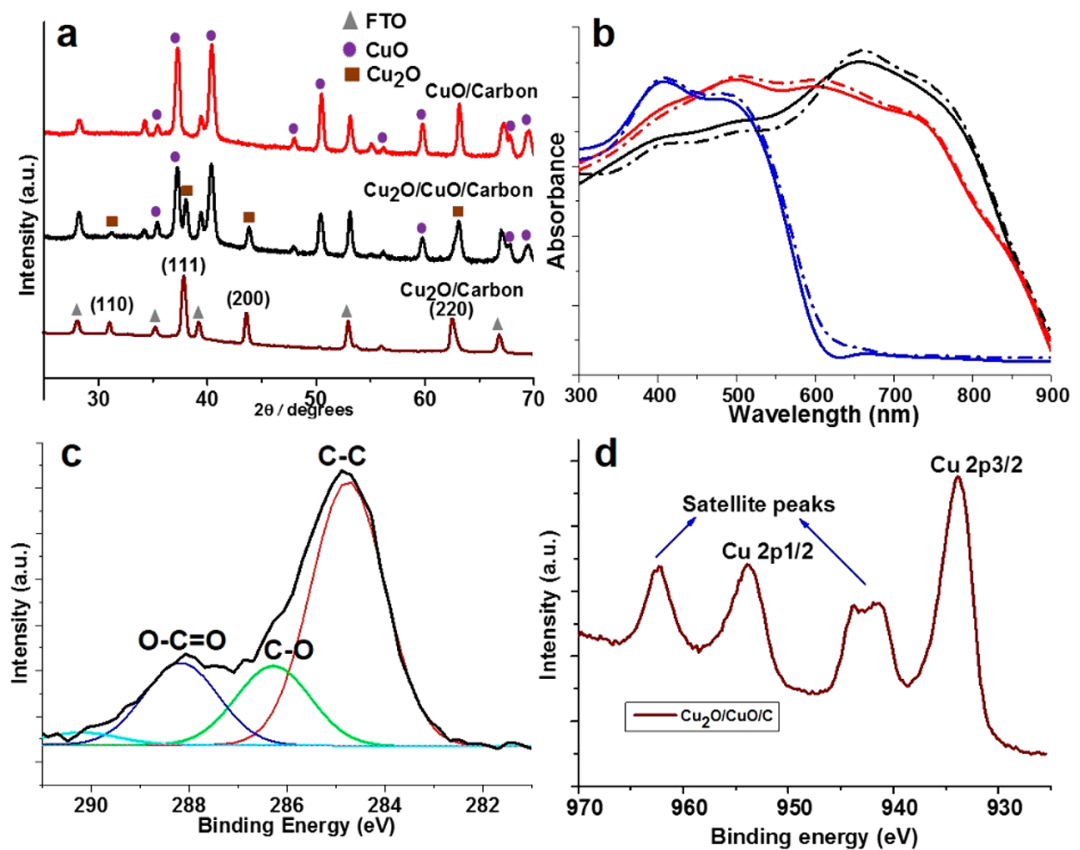

Figure 4. Characterization of copper oxide samples (3000 s electrodeposition time) of different phases. (a) X-ray diffraction patterns of samples $\mathrm{Cu}_{2} \mathrm{O} / \mathrm{C}$ (brown line), $\mathrm{Cu}_{2} \mathrm{O} / \mathrm{CuO} / \mathrm{C}$ (black line), and $\mathrm{CuO} / \mathrm{C}$ (red line). (b) UV-vis absorbance spectra of $\mathrm{Cu}_{2} \mathrm{O}$ (blue line), $\mathrm{CuO}$ (black line), and $\mathrm{Cu}_{2} \mathrm{O} / \mathrm{CuO}$ (red line) with (dotted line) and without (solid line) a carbon layer, derived from diffuse reflectance spectra. XPS core level spectra of the (c) C 1 s and (d) $\mathrm{Cu} 2 \mathrm{p}$ regions of the $\mathrm{Cu}_{2} \mathrm{O} / \mathrm{CuO} / \mathrm{C}$ sample.

field (HAADF) images (insets) with $\mathrm{Cu}$ and $\mathrm{C}$ elemental mapping illustrate the $\mathrm{Cu}_{2} \mathrm{O}$ and $\mathrm{Cu}_{2} \mathrm{O} / \mathrm{CuO}$ heterostructures covered with a high quality amorphous carbon layer.

The XRD spectra of deposited carbon-coated $\mathrm{Cu}_{2} \mathrm{O}, \mathrm{CuO}$ (made by full thermal oxidation of pregrown $\mathrm{Cu}_{2} \mathrm{O}$ ), and
$\mathrm{Cu}_{2} \mathrm{O} / \mathrm{CuO}$ photocathode thin films on FTO with a $3000 \mathrm{~s}$ electrodeposition time are presented in Figure 4a. The $\mathrm{Cu}_{2} \mathrm{O}$ sample exhibited strong diffraction peaks of (110), (111), and (200), corresponding to single-phase cubic $\mathrm{Cu}_{2} \mathrm{O}$. The film after annealing in oxygen flow at $400{ }^{\circ} \mathrm{C}$ for $3 \mathrm{~h}$ exhibited the 


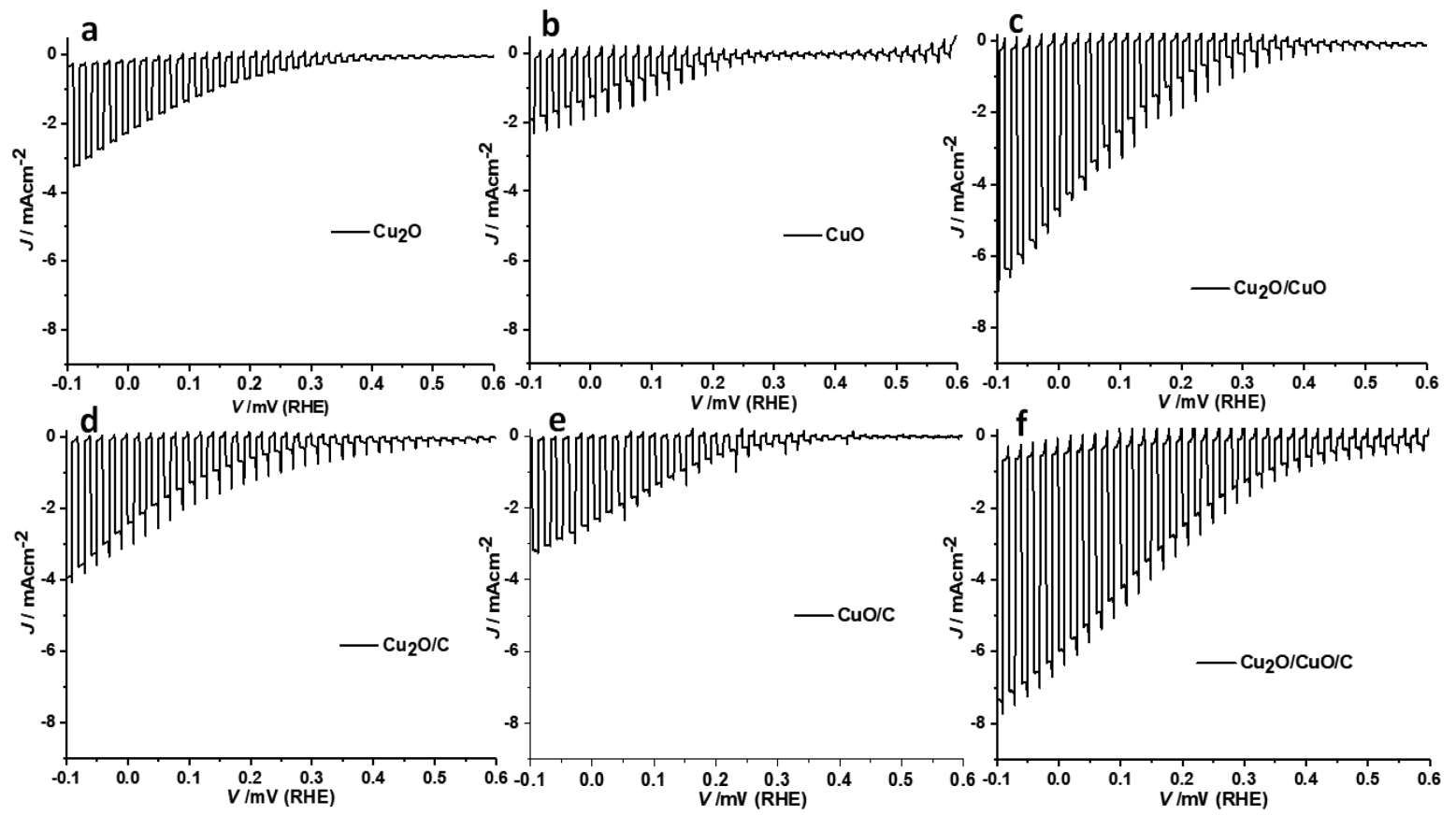

Figure 5. PEC performance of noncoated $(\mathrm{a}-\mathrm{c})$ and coated $(\mathrm{d}-\mathrm{f})$ copper oxide photocathodes (deposition time $=3000 \mathrm{~s}$, carbon layer $=15 \mathrm{~nm})$ under simulated AM $1.5 \mathrm{G}$ chopped illumination.

typical reflections of monoclinic $\mathrm{CuO}$ with distinct peaks for the (111), (200), and (020) crystal planes, while peaks for $\mathrm{Cu}_{2} \mathrm{O}$ were completely absent, indicating the successful oxidation of $\mathrm{Cu}_{2} \mathrm{O}$ to $\mathrm{CuO}$. When annealing in oxygen at $400{ }^{\circ} \mathrm{C}$ for $15 \mathrm{~min}$ to $1 \mathrm{~h}$, the XRD results confirmed the presence of both $\mathrm{Cu}_{2} \mathrm{O}$ and $\mathrm{CuO}$ (Figure S4).

To evaluate the optical absorption properties of the photocathode films, UV-vis diffuse reflectance spectra were measured (Figure 4b). The light absorption properties of the carbon-coated $\mathrm{Cu}_{2} \mathrm{O}$ and the $\mathrm{Cu}_{2} \mathrm{O} / \mathrm{CuO}$ heterostructured films are important to evaluate their use as photocatalysts for HER. The color of the as-deposited $\mathrm{Cu}_{2} \mathrm{O}$ films ranged from bright yellow to dark red upon increase of the thickness (Figure S5a). After thermal oxidation, the front side of the film changed to black, indicating the formation of $\mathrm{CuO}$ (Figure $\mathrm{S} 5 \mathrm{~b})$. The yellowish-orange color was still visible when inspecting the sample from the backside (Figure $\mathrm{S} 5 \mathrm{~b}$ ), implying that part of the $\mathrm{Cu}_{2} \mathrm{O}$ was still present. However, upon extended oxidation, pure $\mathrm{CuO}$ was visible with absence of the color of $\mathrm{Cu}_{2} \mathrm{O}$ (Figure S5b). Pure $\mathrm{Cu}_{2} \mathrm{O}$ has an absorption edge at about $600 \mathrm{~nm}$ (Figure 4b). In contrast, the absorption edge of the $\mathrm{Cu}_{2} \mathrm{O} / \mathrm{CuO}$ heterostructure is extended to approximately $900 \mathrm{~nm}$ as a result of the low $\mathrm{CuO}$ band gap energy.

Conversion of the UV-vis data into Tauc plots is a common method to determine the band gap energy of a semiconductor, employing the Kubelka-Munk theory. ${ }^{64-66}$ We confirmed the different band gaps of $\mathrm{Cu}_{2} \mathrm{O}, \mathrm{Cu}_{2} \mathrm{O} / \mathrm{CuO}$, and $\mathrm{CuO}$ of 2.15, 1.72 , and $1.54 \mathrm{eV}$, respectively. A minor shift in band gap energies occurred upon carbon layer deposition on the $\mathrm{Cu}_{2} \mathrm{O}$ / $\mathrm{CuO}$ heterostructures (Figure S6). Minor variation of the band gap energy may lead to a slightly improved absorptivity of the material.

The concentration of the aqueous glucose solution plays an important role in controlling the thickness of the final carbon layer on the copper oxide surface. Due to increase of the carbon layer thickness, light absorption in the visible light region was compromised (Figure S7). More importantly, the SEM and TEM images (Figures 1-3) of the $15 \mathrm{~nm}$ thin carbon-coated $\mathrm{Cu}_{2} \mathrm{O}$ and $\mathrm{Cu}_{2} \mathrm{O} / \mathrm{CuO}$ heterostructures clearly show that the surfaces were smooth with no noticeable fractures. Apparently, the carbon layer helps to maintain the integrity of the heterostructures compared with the remaining heterostructures, the images (Figure S7a-f and Figure S8) of which showed the presence of isolated fractures, which would be unattractive for PEC application of such a photocathode due to an enhanced tendency toward photocorrosion. From a combined perspective of layer conformability and light absorption, the thickness of the carbon layer needs optimization to obtain a higher active performance and better stability for copper oxides as photocatalysts in water reduction.

XPS measurements were performed on the $\mathrm{Cu}_{2} \mathrm{O} / \mathrm{CuO} / \mathrm{C}$ heterostructures to provide insight into the elemental composition of the material. High-resolution XPS spectra for $\mathrm{C} 1 \mathrm{~s}$ and $\mathrm{Cu} 2 \mathrm{p}$ core levels are presented in Figure $4 \mathrm{c}$ and $\mathrm{d}$. The C spectrum shows a strong peak at $284.8 \mathrm{eV}$, corresponding to graphitic carbon, implying the formation of a graphitic carbon layer on the $\mathrm{Cu}_{2} \mathrm{O} / \mathrm{CuO}$ surface (Figure 4c). The other two peaks with lower intensity at 286.5 and $288.4 \mathrm{eV}$, belonging to $\mathrm{C}-\mathrm{O}$ and $\mathrm{O}-\mathrm{C}=\mathrm{O}$, respectively, indicate some retaining oxygen content from the glucose precursor. The XPS $\mathrm{Cu} 2 \mathrm{p}$ region of $\mathrm{Cu}_{2} \mathrm{O} / \mathrm{CuO} / \mathrm{C}$ is shown in Figure $4 \mathrm{~d}$, in which the two sharp and symmetrical peaks at 932.5 and $953.3 \mathrm{eV}$ are assigned to the $\mathrm{Cu} 2 \mathrm{p} \mathrm{3/2}$ and $\mathrm{Cu}$ $2 \mathrm{p} 1 / 2$ levels, respectively, of $\mathrm{CuO}$. The presence of two other (satellite) peaks at higher binding energies, 943.1 and 962.8 $\mathrm{eV}$, also indicates the presence of $\mathrm{CuO}$ on the surface of the substrate. Due to the comparatively high thickness of the $\mathrm{CuO}$, the underlying $\mathrm{Cu}_{2} \mathrm{O}$ is invisible in this analysis.

To investigate the PEC performance of $\mathrm{Cu}_{2} \mathrm{O}, \mathrm{CuO}$, and $\mathrm{Cu}_{2} \mathrm{O} / \mathrm{CuO}$ films, without and with a protecting carbon layer at various thickness on the photocathodes, linear sweep voltammetry measurements were performed in a $1 \mathrm{M} \mathrm{Na}_{2} \mathrm{SO}_{4}$ electrolyte (pH 5.5) under chopped AM 1.5G (100 mW cm ${ }^{-2}$ ) 

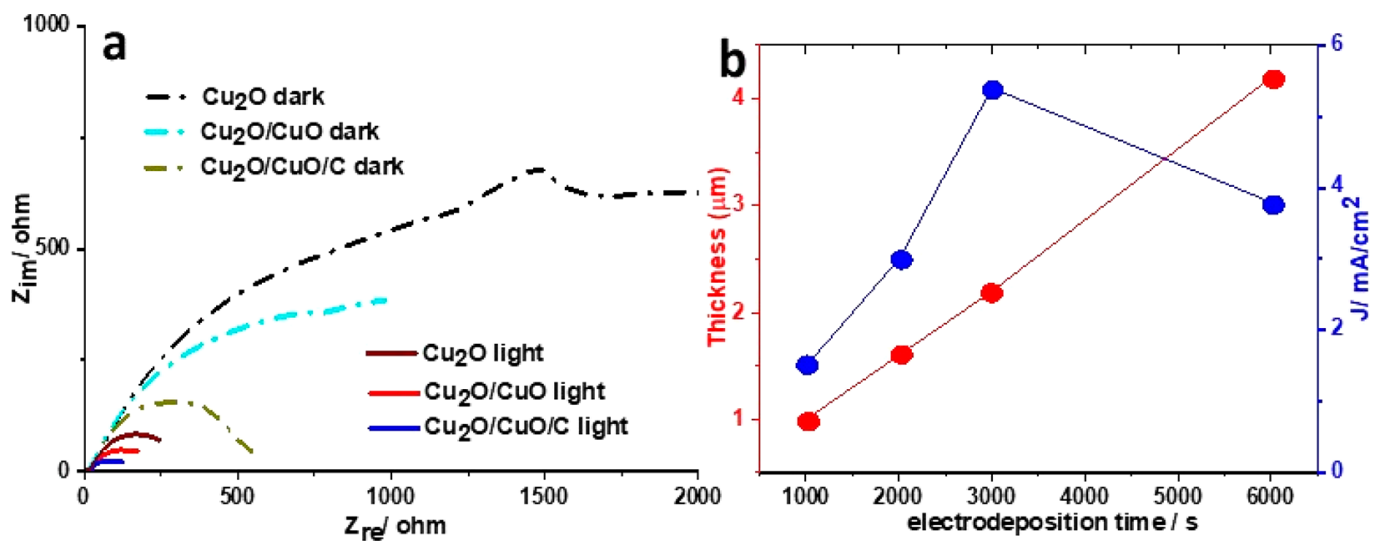

Figure 6. (a) Nyquist plots of $\mathrm{Cu}$ oxide-based photocathodes (carbon-coated and noncoated) both in the dark and under illumination in $1.0 \mathrm{M}$ $\mathrm{Na}_{2} \mathrm{SO}_{4}$ electrolyte at pH 5.5 (at an applied potential of $0 \mathrm{~V}$ vs RHE). (b) Relationship between electrodeposition time with thickness of sample noncoated bare $\mathrm{Cu}_{2} \mathrm{O} / \mathrm{CuO}$ on $\mathrm{FTO}$ and photocurrent density.
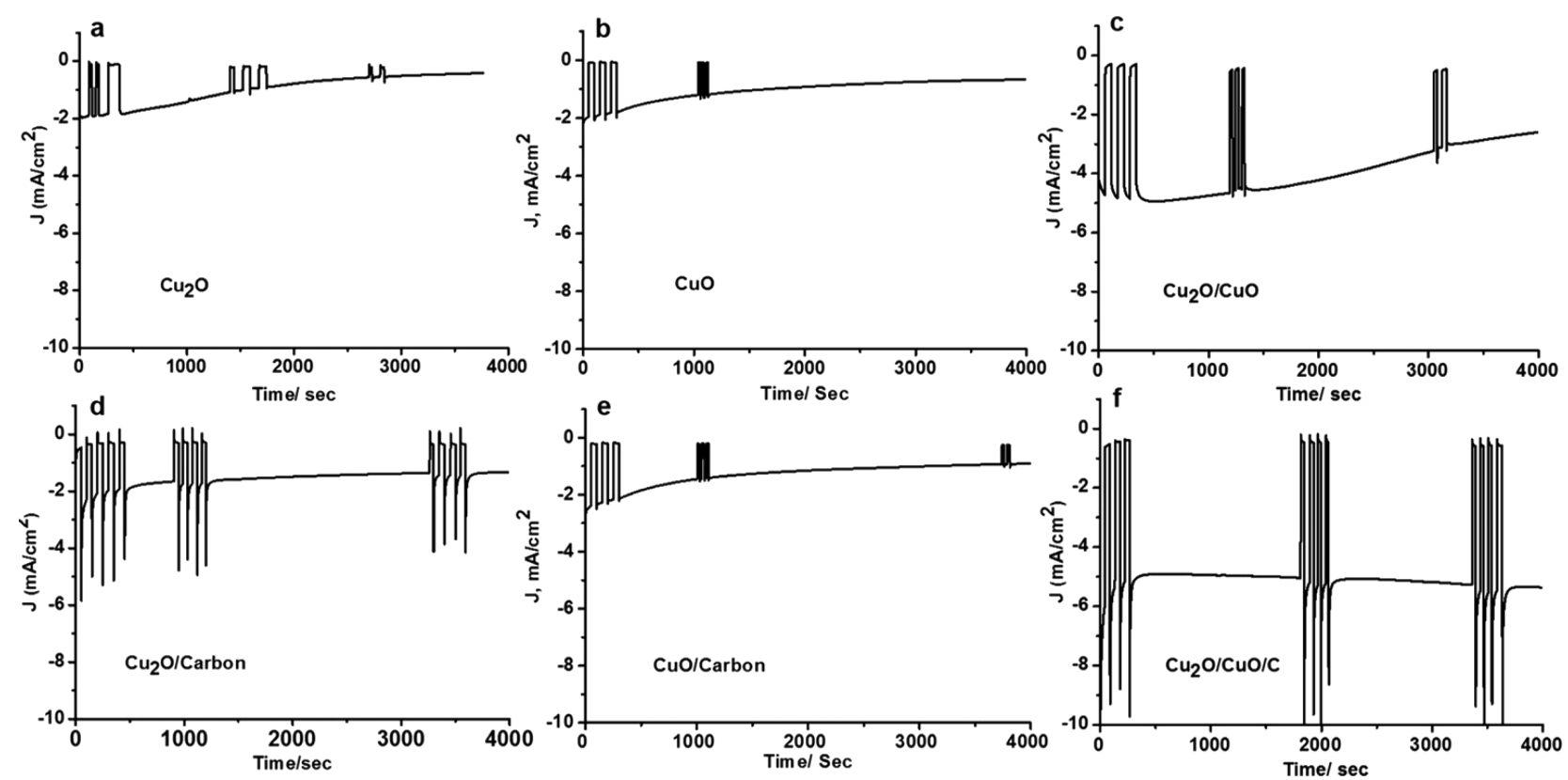

Figure 7. PEC stability of copper oxide $(a-c)$ noncoated and $(d-f)$ carbon-coated photocathode samples.

illumination using a conventional three-electrode system, with the photocathode on FTO, $\mathrm{Ag} / \mathrm{AgCl}$ electrode, and Pt mesh as a working electrode, reference electrode, and counter electrode, respectively. As shown in Figure 5, all photocathodes showed a reductive photocurrent, which was predominantly attributed to the PEC water reduction. The photocurrent densities of the $\mathrm{Cu}_{2} \mathrm{O}$ and $\mathrm{CuO}$ films were not high (Figure $5 \mathrm{a}$ and $b$ ), with values of -2.5 and $-2 \mathrm{~mA} \mathrm{~cm}^{-2}$ at $0.0 \mathrm{~V}$ vs RHE respectively. These values are consistent with results from an earlier study. ${ }^{67}$ The low photocurrent density is attributed to the sluggish reaction kinetics and to self-reduction of the copper oxide film. ${ }^{68,69}$ Upon thermal oxidation for $1 \mathrm{~h}$ at 400 ${ }^{\circ} \mathrm{C}$, the resulting heterostructured $\mathrm{Cu}_{2} \mathrm{O} / \mathrm{CuO}$ film showed enhanced photoactivity compared to the pure $\mathrm{Cu}_{2} \mathrm{O}$ and $\mathrm{CuO}$ films. As can be seen in the Figure $5 c$, the photocurrent density at $0 \mathrm{~V}$ vs $\mathrm{RHE}$ reached $-5.1 \mathrm{~mA} \mathrm{~cm} \mathrm{~cm}^{-2}$, which is more than double compared to those obtained on $\mathrm{Cu}_{2} \mathrm{O}$ and $\mathrm{CuO}$ films. We assume that downward band bending occurs at the interface of the $\mathrm{Cu}_{2} \mathrm{O} / \mathrm{CuO}$ thin film with the electrolyte, which enhances the current density. The carbon-protected thin films gave enhanced current densities (Figure $5 \mathrm{~d}-\mathrm{f}$ ), of which the copper oxide heterostructured photocathode showed a current density of $-6.5 \mathrm{~mA} / \mathrm{cm}^{2}$ at $0 \mathrm{~V}$ vs RHE under simulated 1 sun irradiation, which was the highest photocurrent among all samples tested here. When protecting the $\mathrm{Cu}_{2} \mathrm{O}$ and $\mathrm{Cu}_{2} \mathrm{O} / \mathrm{CuO}$ films with a $15 \mathrm{~nm}$ carbon layer, the enhanced performance is attributed to further facilitating quick electron transfer to the surface and suppressing photocorrosion of the photocathode film. However, the optimized PEC sample (Figure 5f) shows the onset of a dark cathodic current at $\sim 0.15$ $\mathrm{V}$ vs RHE, demonstrating the existence of a non-HER reaction, likely $\mathrm{CuO}$ reduction.

The performance of catalytic HER of the photocathodes under AC response was studied with electrochemical impedance spectroscopy (EIS), both in the dark and under light illumination. This investigation was performed in order to evaluate the charge-transfer resistance $\left(R_{\mathrm{ct}}\right)$ at the photocathode/solution interface. As observed in Figure $6 \mathrm{a}$, the Nyquist plots are strongly affected by the illumination applied onto the PEC cell, indicating a significantly reduced charge 
transfer resistance compared to dark conditions. Both in the dark and under illumination, the charge transfer resistance decreased in the order $\mathrm{Cu}_{2} \mathrm{O}, \mathrm{Cu}_{2} \mathrm{O} / \mathrm{CuO}$, and $\mathrm{Cu}_{2} \mathrm{O} / \mathrm{CuO} / \mathrm{C}$, indicating that illumination promotes charge transfer by the photoinduced enhancement of the charge carrier density. These results support the trend of the photocurrent density described above, signifying that the $\mathrm{Cu}_{2} \mathrm{O} / \mathrm{CuO} / \mathrm{C}$ heterostructure provides facilitated charge transfer across the photocathode material to the solution interface, indicating stronger electronic coupling between the layers. This explains why the heterostructure and carbon-coated photocathodes exhibited the best PEC performance for HER. Figure $6 \mathrm{~b}$ shows the correlation between electrodeposition time to deposit the cuprous oxide layer on the FTO substrate and the thickness of the $\mathrm{Cu}_{2} \mathrm{O} / \mathrm{CuO}$ heterostructure after annealing the samples in $\mathrm{O}_{2}$ atmosphere. The layer thickness ratio between $\mathrm{Cu}_{2} \mathrm{O}$ and $\mathrm{CuO}$ in the mixed oxide layer depends on the initial $\mathrm{Cu}_{2} \mathrm{O}$ layer thickness. This corroborates the observed effect of the $\mathrm{Cu}_{2} \mathrm{O}$ electrodeposition time on the PEC activity of the $\mathrm{Cu}_{2} \mathrm{O}$ / $\mathrm{CuO}$ heterostructure, as is attributed to an improved efficiency of electron-hole separation and reduced recombination, and to improved light absorption by the underlying $\mathrm{Cu}_{2} \mathrm{O}$ film.

Apparently, fabricating $\mathrm{Cu}_{2} \mathrm{O} / \mathrm{CuO}$ heterostructure films with the proper layer thickness is crucial to obtain an improved photoactivity. As mentioned previously, using $\mathrm{CuO}$ as a top layer led to reduced photocorrosion of the $\mathrm{Cu}_{2} \mathrm{O}$ as well as reduced charge carrier recombination. Still, the photocatalyst is limited by the unfavorable ratio of the optical absorption path length and the carrier transport distance. As shown in Figure $6 \mathrm{~b}$, the $\mathrm{Cu}_{2} \mathrm{O} / \mathrm{CuO}$ heterostructure films resulting from lower electrodeposition times (1000 and $2000 \mathrm{~s})$ have an insufficiently thick $\mathrm{Cu}_{2} \mathrm{O}$ film to provide good PEC activity. This may in part be due to a nonhomogeneous film with pits, exposing areas of the FTO surface and, as a consequence, showing lower photocurrents. However, the $\mathrm{Cu}_{2} \mathrm{O} / \mathrm{CuO}$

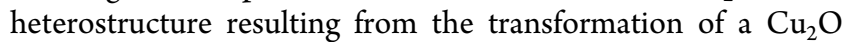
film deposited for $3000 \mathrm{~s}$ gave homogeneous and complete coverage of the FTO substrate and showed the highest photocurrent. However, upon $6000 \mathrm{~s}$ electrodeposition time, the obtained heterostructure photocathode was too thick in comparison to the charge carrier distance, leading to recombination losses and reduced PEC performance.

The photostability of the photocathodes under illumination was evaluated by chronoamperometric measurements at $0 \mathrm{~V}$ vs RHE in $1 \mathrm{M} \mathrm{Na}_{2} \mathrm{SO}_{4}$ electrolyte (Figure 7). The bare $\mathrm{Cu}_{2} \mathrm{O}$ and $\mathrm{CuO}$ photocathodes showed (Figure $7 \mathrm{a}-\mathrm{c}$ ) a low photostability, and after $4000 \mathrm{~s}$ the current density approached zero. The low photostability observed for the bare $\mathrm{Cu}_{2} \mathrm{O}$ and $\mathrm{CuO}$ films is attributed to the band position of the copper oxide photocathodes and self-reduction into metallic $\mathrm{Cu}$ by the photogenerated electrons. Upon formation of a $\mathrm{Cu}_{2} \mathrm{O} / \mathrm{CuO}$ heterostructure, the activity was enhanced two times compared to the bare $\mathrm{Cu}_{2} \mathrm{O}$ and $\mathrm{CuO}$ photocathodes, and the photostability was also improved, resulting in significant PEC activity after $4000 \mathrm{~s}$ under illumination and negligible dark currents. The average photocurrent density remained at about $55 \%$, indicating a decay of below $45 \%$. In fact, this is a rather small decay compared to single copper oxide photocathodes without a protecting layer. Apparently, the outer $\mathrm{CuO}$ layer already protects the underlying $\mathrm{Cu}_{2} \mathrm{O}$ film to some extent from corrosion, which provides a better photostability. However, the improvement is insufficient for long-term $\mathrm{PEC}$ performance, as expected from the redox potentials of $\mathrm{CuO}$ and $\mathrm{Cu}_{2} \mathrm{O}$.
Modifying the $\mathrm{Cu}_{2} \mathrm{O} / \mathrm{CuO}$ heterostructure surface with stable nanometer-thick materials (such as $\mathrm{TiO}_{2}, \mathrm{ZnO}$, g- $\mathrm{C}_{3} \mathrm{~N}_{4}$, and carbon) can further improve the photostability. As shown in Figure $7 \mathrm{~d}-\mathrm{f}$, all carbon-protected $\mathrm{Cu}_{2} \mathrm{O}, \mathrm{CuO}$, and $\mathrm{Cu}_{2} \mathrm{O}$ / $\mathrm{CuO}$ thin films exhibited significantly enhanced photocurrents and photostabilities compared with the nonprotected photocathodes (Figure $7 \mathrm{a}-\mathrm{c}$ ). As presented in Figure 7, all photocathodes showed currents even when the light was off, i.e., a dark current, and particularly the nonprotected photocathodes showed higher dark currents compared to carbon-protected photocathodes. Probably, direct contact of the photocathode surface with the electrolyte results in surface degradation and photocorrosion by constant surface charging. Upon applying an optimum $15 \mathrm{~nm}$ thickness of carbon on the photocathodes, the photocorrosion of the surface was inhibited. The most optimal case was observed again for the $\mathrm{Cu}_{2} \mathrm{O} / \mathrm{CuO} / \mathrm{C}$ heterostructure film, which showed maintained performance for over $1 \mathrm{~h}$.

To examine the cause for the decrease in PEC stability of the photocathodes, XRD and XPS spectra were taken for the $\mathrm{Cu}_{2} \mathrm{O} / \mathrm{C}$ and $\mathrm{Cu}_{2} \mathrm{O} / \mathrm{CuO} / \mathrm{C}$ samples after the PEC measurements were performed (Figure S8). The XRD spectrum shows the appearance of new peaks $44.2^{\circ}$ and $51.3^{\circ}$, which indicates the formation of $\mathrm{Cu}$ particles on the surface. The significant morphological surface changes were observed clearly in SEM images after PEC testing (Figure S9). In agreement with the elemental compositions obtained from the XPS spectra, these data confirmed photocorrosion and concomitant morphological changes. The PEC performance of $\mathrm{Cu}_{2} \mathrm{O} / \mathrm{CuO}$ heterostructured samples with carbon coatings of various thicknesses is presented in Figure S10. The photocurrents increased with increasing carbon layer thickness from 5 to $15 \mathrm{~nm}$, while for a thickness of $20 \mathrm{~nm}$ it slightly decreased. These results confirm that a $15 \mathrm{~nm}$ carbon coating is the most optimal layer thickness regarding PEC performance and stability.

Furthermore, we studied the long-term stability at $0.3 \mathrm{~V}$ vs RHE (i.e., $-0.2 \mathrm{~V}$ vs $\mathrm{Ag} / \mathrm{AgCl}$ ) under simulated $\mathrm{AM} 1.5 \mathrm{G}$ illumination. The heterostructure photocathode showed excellent stability over $50 \mathrm{~h}$ (Figure S11a) with continuous hydrogen generation, and the amount of hydrogen evolved was monitored over time (Figure S11b). The data confirm that the measured photocurrent of the $\mathrm{Cu}_{2} \mathrm{O} / \mathrm{CuO} / \mathrm{C}$ photocathode arises from the hydrogen evolution reaction by water splitting rather than any other unwanted side reactions. The amount of $\mathrm{H}_{2}$ evolved from the $\mathrm{Cu}_{2} \mathrm{O} / \mathrm{CuO} / \mathrm{C}$ heterostructure photocathode at $0.3 \mathrm{~V}$ vs RHE in the initial $5 \mathrm{~h}$ was $48 \mu \mathrm{mol}$. This corresponds to an initial faradaic efficiency of $92 \%$ (the remainder is tentatively attributed to incomplete gas collection and/or competing electrochemical processes), and there was no major decline in the performance during the test. The results show that stable operation is possible without degradation, as long as the copper oxide heterostructure is protected and the electrode is operated at a slightly higher potential $(0.3 \mathrm{~V}$ vs $\mathrm{RHE})$. The strongly increased preference for hydrogen formation over the competing $\mathrm{Cu}$ oxide reduction is attribution to a kinetic effect induced by the passivation layer.

The IPCE measurements indicate an enhanced absorption of the carbon coated $-\mathrm{Cu}_{2} \mathrm{O} / \mathrm{CuO}$ photoelectrode in the long wavelength region (Figure $\mathrm{S} 11 \mathrm{c}$ ). This is attributed to a redshift of the band gap by the use of $\mathrm{CuO}$ and by the conformal coating of the carbon film. The improved IPCE performance aligns with the UV-vis diffuse reflectance spectra. A maximum 
IPCE of $70 \%$ was achieved at a wavelength of $580 \mathrm{~nm}$, which indicates efficient inhibition of charge carrier recombination.

Photoluminescence (PL) emission spectra of $\mathrm{Cu}_{2} \mathrm{O}, \mathrm{Cu}_{2} \mathrm{O}$ / $\mathrm{CuO}$, and of the $\mathrm{Cu}_{2} \mathrm{O} / \mathrm{CuO} / \mathrm{C}$ heterostructure were measured at an excitation wavelength of $432 \mathrm{~nm}$ (Figure S11d) to provide insight into the efficiency of photogenerated charge carrier separation. A higher PL emission peak intensity corresponds to a higher carrier recombination rate, that is, a shorter lifetime of the electron-hole pairs. ${ }^{70,71}$ Bare $\mathrm{Cu}_{2} \mathrm{O}$ exhibited an intense peak at $650 \mathrm{~nm}$, whereas both the signals of other heterojunctions with and without carbon layers were evidently quenched, indicating that both $\mathrm{CuO}$ and carbon can participate in separation and transportation of charge carriers effectively from $\mathrm{Cu}_{2} \mathrm{O}$.

Apparently, the carbon coating promotes both the photocurrent and the photostability. Also the incorporation of $\mathrm{CuO}$ improves the performance of a $\mathrm{Cu}_{2} \mathrm{O}$ photocathode. Both materials are shown in a band diagram (Figure S12). Most likely, the deposition of a carbon layer and its energy band levels provide efficient electron transport to the surface where hydrogen is produced. ${ }^{72-74}$ This is supported by the chargetransfer resistance $\left(R_{\mathrm{ct}}\right)$ in impedance spectroscopy (Figure 6a) and the PL peak intensity (Figure S11d).

\section{CONCLUSIONS}

In the work presented here, we have demonstrated tuning of the electrodeposition time and application of a carbon protecting layer by solution processing, which combined resulted in $\mathrm{Cu}_{2} \mathrm{O} / \mathrm{CuO}$ heterostructure photocathodes with improved current density and stability. The $\mathrm{Cu}_{2} \mathrm{O}$ film morphology and coverage on FTO substrates showed dependence on deposition time. With increasing deposition time at constant potential, the crystal grain size increased, and many truncated cubes exposed the triangular faces parallel to the substrate. The PEC performance, as characterized by photocurrent density and photostability, was enhanced significantly by incorporating an optimum thickness of the carbon protection layer. The best performing devices showed photocurrents up to 6.5 and $7.5 \mathrm{~mA} / \mathrm{cm}^{-2}$ at a potential of 0 and $-0.1 \mathrm{~V}$ vs $\mathrm{RHE}$ at $\mathrm{pH} 5.5$, respectively. Conformal coating of a carbon protection layer allows stable operation at low bias for $50 \mathrm{~h}$. To the best of our knowledge, this is the best performance reported for a $\mathrm{Cu}_{2} \mathrm{O} / \mathrm{CuO}$ heterostructured photocathode in the absence of a cocatalyst. The carbon protection strategy prohibits surface degradation and photocorrosion efficiently. The results presented here suggest that the key factors to an efficient and stable performance are (i) electrodeposition time, (ii) thermal oxidation to create a heterostructured copper oxide layer, and (iii) the combination of a high quality surface $\mathrm{p}-\mathrm{n}$ junction with a carbon protection layer. The carbon coating suppresses a dark current that results from degradation or corrosion at the surface and provides enhanced electron transfer. Overall, the photocathodes made from earth-abundant copper oxide materials and stabilized with an easily applied and cost-effective solution deposition process may become promising candidates for practical solar fuel production.

\section{EXPERIMENTAL SECTION}

Materials. Copper sulfate pentahydrate $\left(\mathrm{CuSO}_{4} \cdot 5 \mathrm{H}_{2} \mathrm{O}\right.$, SigmaAldrich, $99 \%)$, lactic acid $\left(\mathrm{C}_{3} \mathrm{H}_{6} \mathrm{O}_{3}\right.$, Sigma-Aldrich, $\left.85 \%\right)$, dipotassium hydrogen phosphate $\left(\mathrm{K}_{2} \mathrm{HPO}_{4}\right.$, Merck, $\left.99 \%\right)$, potassium hydroxide pellets ( $\mathrm{KOH}$, Acros organics, $85 \%$ ), sodium sulfate $\left(\mathrm{Na}_{2} \mathrm{SO}_{4}\right.$, Sigma-
Aldrich, 99\%), formic acid (HCOOH, Merck, 98-100\%), and fluorine-doped tin oxide-coated glass slides (FTO, Sigma-Aldrich, TEC $7,7 \Omega / s q$ ) were obtained from commercial sources and were used as received. Millipore deionized water (resistivity $>18.2 \mathrm{M} \Omega$ $\mathrm{cm}^{-1}$ ) was used to prepare all solutions.

Electrodeposition of $\mathrm{Cu}_{2} \mathrm{O}$. The $\mathrm{Cu}_{2} \mathrm{O}$ films were prepared by a time-based amperometric ( $i-t$ curve) deposition method. In brief, the electrodeposition of $\mathrm{Cu}_{2} \mathrm{O}$ was performed using a VersaSTAT 4 potentiostat using a two-electrode configuration, in which the FTO substrate served as the working electrode and a platinum mesh as the counter electrode. The deposition was conducted at a potential difference of $-1.25 \mathrm{~V}$ in an electrolyte solution consisting of $0.2 \mathrm{M}$ $\mathrm{CuSO}_{4}, 3 \mathrm{M}$ lactic acid, and $0.5 \mathrm{M} \mathrm{K}_{2} \mathrm{HPO}_{4}$ buffer. The $\mathrm{pH}$ of the electrolyte solution was adjusted to 12 by the addition of $3 \mathrm{M} \mathrm{KOH}$ solution. The thickness of the $\mathrm{Cu}_{2} \mathrm{O}$ films was controlled by varying the deposition time (1000, 3000, and $6000 \mathrm{~s})$ while the temperature was kept at $40{ }^{\circ} \mathrm{C}$ using a hot water bath with an in situ temperature probe.

Fabrication of $\mathrm{Cu}_{2} \mathrm{O} / \mathrm{CuO}$ and $\mathrm{CuO}$ Heterostructures. The $\mathrm{Cu}_{2} \mathrm{O} / \mathrm{CuO}$ heterostructures were fabricated by thermal oxidation of as-deposited $\mathrm{Cu}_{2} \mathrm{O}$ films (deposition time $3000 \mathrm{~s}$ ) at $400{ }^{\circ} \mathrm{C}$ for $1 \mathrm{~h}$ in the presence of air. The pure $\mathrm{CuO}$ film was prepared by thermal oxidation of the $\mathrm{Cu}_{2} \mathrm{O}$ film in air at $400{ }^{\circ} \mathrm{C}$ for $3 \mathrm{~h}$ (at a ramping rate of $10{ }^{\circ} \mathrm{C} / \mathrm{min}$, and all samples were collected after cooling down naturally).

Carbon Coating on $\mathrm{Cu}_{2} \mathrm{O}, \mathrm{CuO}$, and $\mathrm{Cu}_{2} \mathrm{O} / \mathrm{CuO}$ Heterostructure Photocathodes. Carbon coating layers on $\mathrm{Cu}_{2} \mathrm{O}$ and $\mathrm{CuO}$ and of $\mathrm{Cu}_{2} \mathrm{O} / \mathrm{CuO}$ photocathodes were achieved by hydrothermal treatment of glucose followed by annealing at high temperature in air and $\mathrm{N}_{2}$ atmosphere, respectively. Prepared copper oxide photocathodes were immersed in $20 \mathrm{~mL}$ of an aqueous glucose $(3 \mathrm{mg} / \mathrm{mL})$ solution for $8 \mathrm{~h}$ and dried at ambient condition. The glucose-coated photocathodes were kept in a furnace for $4 \mathrm{~h}$ at 400 ${ }^{\circ} \mathrm{C}$, resulting in melting and carbonization of glucose to form an activated carbon layer. ${ }^{48}$

Material Characterization. XRD measurements were performed on a Bruker D2 ( $\mathrm{Cu} \mathrm{K} \alpha$ source) diffractometer. UV/vis diffuse reflectance spectra (DRS) were recorded with a UV/vis spectrophotometer (Thermo Scientific, Evolution 600), and the reflectance data were converted to Kulbelka-Munk plots and the corresponding Tauc plots. A Sirion HR-SEM (FEI Instruments) instrument was used for SEM experiments. TEM imaging of the deposited photocathodes was performed using a Philips CM300ST-FEG microscope equipped with a Kevex EDX detector. The X-ray photoelectron spectroscopy (XPS) measurements were performed on a Quantera SXM (Physical Electronics) instrument, equipped with an $\mathrm{Al} \mathrm{K} \alpha$ X-ray source $(1486.6 \mathrm{eV})$. Photoluminescence (PL) spectra were recorded at a PerkinElmer ls 55 fluorescence spectrometer.

PEC Measurements. To measure the photoelectrical characteristics (IPCE and PEC) of the $\mathrm{Cu}_{2} \mathrm{O} / \mathrm{CuO} / \mathrm{C}$ heterostructure photocathode, samples were positioned perpendicular to a $300 \mathrm{~W}$ xenon arc light source, which was filtered to modify its output to AM 1.5G spectrally. Upon installation of the lamp, the lamp was calibrated by VLSI Standards Inc. Before every measurement the lamp was checked by a calibrated Si solar cell, supplied by VLSI Standards Inc., for spectral mismatch. PEC measurements were recorded on a VersaSTAT 4 potentiostat using a linear voltage sweep from -0.1 to $0.6 \mathrm{~V}$ at a rate of $0.2 \mathrm{mV} \mathrm{s}^{-1}$. The three-electrode configuration consisted of an aqueous solution of $1 \mathrm{M} \mathrm{Na}_{2} \mathrm{SO}_{4}$ at $\mathrm{pH} 5.5$ with $0.1 \mathrm{M}$ formic acid as the electrolyte, $\mathrm{Ag} / \mathrm{AgCl}$ in saturated $\mathrm{KCl}$ as a reference electrode, Pt mesh as a counter electrode, and the prepared copper oxide photocathode as a working electrode. Electrochemical impedance spectroscopy (EIS) was performed using an AC amplitude of $10 \mathrm{mV}$ and a frequency range between $100 \mathrm{kHz}$ to $0.1 \mathrm{~Hz}$. The measured EIS data were obtained at an applied bias of $0 \mathrm{~V}$ vs RHE at room temperature. The potential was converted to the RHE reference electrode by the Nernst equation:

$$
E=E_{\mathrm{Ag} / \mathrm{AgCl}}+0.059 \mathrm{pH}+E_{\mathrm{Ag} / \mathrm{AgCl}}^{\circ}
$$

where 
$E_{\mathrm{Ag} / \mathrm{AgCl}}^{\circ}=0.197 \mathrm{~V}$ at $25^{\circ} \mathrm{C}$

Hydrogen Production. The hydrogen evolution was measured using a Teflon cell connected to a highly sensitive gas chromatograph (CompactGC Interscience). The GC was equipped with a pulsed discharge detector to determine the amount $\mathrm{H}_{2}$ in the argon carrier gas. Argon was flowed at $5 \mathrm{~mL} / \mathrm{min}$ through the $1 \mathrm{M} \mathrm{Na}_{2} \mathrm{SO}_{4}$ electrolyte of the PEC cell (see PEC Measurements, above).

\section{ASSOCIATED CONTENT}

\section{S Supporting Information}

The Supporting Information is available free of charge on the ACS Publications website at DOI: 10.1021/acsaem.9b01290.

The $i-t$ curves in electrodeposition of photocathodes; SEM and XRD characterization details; and UV-vis absorption spectra of photocathodes and their corresponding PEC performance with long-run photostability measurements (PDF)

\section{AUTHOR INFORMATION}

\section{Corresponding Author}

*E-mail: j.huskens@utwente.nl.

\section{ORCID $\odot$}

Jurriaan Huskens: 0000-0002-4596-9179

\section{Notes}

The authors declare no competing financial interest.

\section{ACKNOWLEDGMENTS}

The authors thank Wouter Vijselaar for helpful discussions and for his assistance with the PEC measurements; Gerard Kip for XPS measurements; and Rico Keim for the TEM and EDX characterizations. We thank Alexander Milbrat and Guido Mul for use of the solar simulator. P.P.K. is grateful to the Karnataka state government for providing a scholarship under the D. Devraj Urs Videshi Vyasanga Vetana scheme.

\section{REFERENCES}

(1) Kamat, P. V. Meeting the Clean Energy Demand: Nanostructure Architectures for Solar Energy Conversion. J. Phys. Chem. C 2007, 111 (7), 2834-2860.

(2) Ardo, S.; Fernandez Rivas, D.; Modestino, M. A.; Schulze Greiving, V.; Abdi, F. F.; Alarcon Llado, E.; Artero, V.; Ayers, K.; Battaglia, C.; Becker, J.-P.; Bederak, D.; Berger, A.; Buda, F.; Chinello, E.; Dam, B.; Di Palma, V.; Edvinsson, T.; Fujii, K.; Gardeniers, H.; Geerlings, H.; H. Hashemi, S. M.; Haussener, S.; Houle, F.; Huskens, J.; James, B. D.; Konrad, K.; Kudo, A.; Kunturu, P. P.; Lohse, D.; Mei, B.; Miller, E. L.; Moore, G. F.; Muller, J.; Orchard, K. L.; Rosser, T. E.; Saadi, F. H.; Schüttauf, J.-W.; Seger, B.; Sheehan, S. W.; Smith, W. A.; Spurgeon, J.; Tang, M. H.; van de Krol, R.; Vesborg, P. C. K.; Westerik, P. Pathways to electrochemical solar-hydrogen technologies. Energy Environ. Sci. 2018, 11 (10), 2768-2783.

(3) Detz, R. J.; Reek, J. N. H.; van der Zwaan, B. C. C. The future of solar fuels: when could they become competitive? Energy Environ. Sci. 2018, 11 (7), 1653-1669.

(4) Yu, L.; Zhou, H.; Sun, J.; Qin, F.; Yu, F.; Bao, J.; Yu, Y.; Chen, S.; Ren, $\mathrm{Z}$. $\mathrm{Cu}$ nanowires shelled with $\mathrm{NiFe}$ layered double hydroxide nanosheets as bifunctional electrocatalysts for overall water splitting. Energy Environ. Sci. 2017, 10 (8), 1820-1827.

(5) Azevedo, J.; Steier, L.; Dias, P.; Stefik, M.; Sousa, C. T.; Araújo, J. P.; Mendes, A.; Graetzel, M.; Tilley, S. D. On the stability enhancement of cuprous oxide water splitting photocathodes by low temperature steam annealing. Energy Environ. Sci. 2014, 7 (12), 4044-4052.

(6) Pinaud, B. A.; Benck, J. D.; Seitz, L. C.; Forman, A. J.; Chen, Z.; Deutsch, T. G.; James, B. D.; Baum, K. N.; Baum, G. N.; Ardo, S.;
Wang, H.; Miller, E.; Jaramillo, T. F. Technical and economic feasibility of centralized facilities for solar hydrogen production via photocatalysis and photoelectrochemistry. Energy Environ. Sci. 2013, 6 (7), 1983-2002.

(7) Kudo, A.; Miseki, Y. Heterogeneous photocatalyst materials for water splitting. Chem. Soc. Rev. 2009, 38 (1), 253-278.

(8) Chen, X.; Shen, S.; Guo, L.; Mao, S. S. Semiconductor-based Photocatalytic Hydrogen Generation. Chem. Rev. 2010, 110 (11), 6503-6570.

(9) Chen, Z.; Jaramillo, T. F.; Deutsch, T. G.; Kleiman-Shwarsctein, A.; Forman, A. J.; Gaillard, N.; Garland, R.; Takanabe, K.; Heske, C.; Sunkara, M.; McFarland, E. W.; Domen, K.; Miller, E. L.; Turner, J. A.; Dinh, H. N. Accelerating materials development for photoelectrochemical hydrogen production: Standards for methods, definitions, and reporting protocols. J. Mater. Res. 2010, 25 (1), 3-16.

(10) Osterloh, F. E. Inorganic nanostructures for photoelectrochemical and photocatalytic water splitting. Chem. Soc. Rev. 2013, 42 (6), 2294-2320.

(11) Walter, M. G.; Warren, E. L.; McKone, J. R.; Boettcher, S. W.; Mi, Q.; Santori, E. A.; Lewis, N. S. Solar Water Splitting Cells. Chem. Rev. 2010, 110 (11), 6446-6473.

(12) Luo, J.; Im, J.-H.; Mayer, M. T.; Schreier, M.; Nazeeruddin, M. K.; Park, N.-G.; Tilley, S. D.; Fan, H. J.; Grätzel, M. Water photolysis at $12.3 \%$ efficiency via perovskite photovoltaics and Earth-abundant catalysts. Science 2014, 345 (6204), 1593.

(13) Alexander, B. D.; Kulesza, P. J.; Rutkowska, I.; Solarska, R.; Augustynski, J. Metal oxide photoanodes for solar hydrogen production. J. Mater. Chem. 2008, 18 (20), 2298-2303.

(14) Saito, R.; Miseki, Y.; Nini, W.; Sayama, K. Discovery of Overcoating Metal Oxides on Photoelectrode for Water Splitting by Automated Screening. ACS Comb. Sci. 2015, 17 (10), 592-599.

(15) Scheuermann, A. G.; Lawrence, J. P.; Kemp, K. W.; Ito, T.; Walsh, A.; Chidsey, C. E. D.; Hurley, P. K.; McIntyre, P. C. Design principles for maximizing photovoltage in metal-oxide-protected water-splitting photoanodes. Nat. Mater. 2016, 15, 99.

(16) Montoya, J. H.; Seitz, L. C.; Chakthranont, P.; Vojvodic, A.; Jaramillo, T. F.; Nørskov, J. K. Materials for solar fuels and chemicals. Nat. Mater. 2017, 16, 70.

(17) Jiang, C.; Moniz, S. J. A.; Wang, A.; Zhang, T.; Tang, J. Photoelectrochemical devices for solar water splitting - materials and challenges. Chem. Soc. Rev. 2017, 46 (15), 4645-4660.

(18) Yan, Q.; Yu, J.; Suram, S. K.; Zhou, L.; Shinde, A.; Newhouse, P. F.; Chen, W.; Li, G.; Persson, K. A.; Gregoire, J. M.; Neaton, J. B. Solar fuels photoanode materials discovery by integrating highthroughput theory and experiment. Proc. Natl. Acad. Sci. U. S. A. 2017, 114 (12), 3040.

(19) Zhou, Y. C.; Switzer, J. A. Galvanostatic electrodeposition and microstructure of copper (I) oxide film. Mater. Res. Innovations 1998, 2 (1), 22-27.

(20) Paracchino, A.; Laporte, V.; Sivula, K.; Grätzel, M.; Thimsen, E. Highly active oxide photocathode for photoelectrochemical water reduction. Nat. Mater. 2011, 10, 456.

(21) Meyer, B. K.; Polity, A.; Reppin, D.; Becker, M.; Hering, P.; Klar, P. J.; Sander, T.; Reindl, C.; Benz, J.; Eickhoff, M.; Heiliger, C.; Heinemann, M.; Bläsing, J.; Krost, A.; Shokovets, S.; Müller, C.; Ronning, C. Binary copper oxide semiconductors: From materials towards devices. Phys. Status Solidi B 2012, 249 (8), 1487-1509.

(22) Paracchino, A.; Brauer, J. C.; Moser, J.-E.; Thimsen, E.; Graetzel, M. Synthesis and Characterization of High-Photoactivity Electrodeposited Cu2O Solar Absorber by Photoelectrochemistry and Ultrafast Spectroscopy. J. Phys. Chem. C 2012, 116 (13), 7341-7350.

(23) Morales-Guio, C. G.; Tilley, S. D.; Vrubel, H.; Grätzel, M.; Hu, $\mathrm{X}$. Hydrogen evolution from a copper(I) oxide photocathode coated with an amorphous molybdenum sulphide catalyst. Nat. Commun. 2014, 5, 3059.

(24) Minami, T.; Nishi, Y.; Miyata, T. Efficiency enhancement using a $\mathrm{Zn} 1-\mathrm{x}$ Ge $\mathrm{x}-\mathrm{O}$ thin film as an $\mathrm{n}$-type window layer in $\mathrm{Cu} 2 \mathrm{O}$ based heterojunction solar cells. Appl. Phys. Express 2016, 9 (5), No. 052301. 
(25) Wong, K. T.; Zhuk, S.; Masudy-Panah, S.; Dalapati, K. G. Current Status and Future Prospects of Copper Oxide Heterojunction Solar Cells. Materials 2016, 9 (4), 271-291.

(26) Radi, A.; Pradhan, D.; Sohn, Y.; Leung, K. T. Nanoscale Shape and Size Control of Cubic, Cuboctahedral, and Octahedral $\mathrm{Cu}-$ $\mathrm{Cu} 2 \mathrm{O}$ Core-Shell Nanoparticles on $\mathrm{Si}(100)$ by One-Step, Templateless, Capping-Agent-Free Electrodeposition. ACS Nano 2010, 4 (3), $1553-1560$

(27) Bhaumik, A.; Shearin, A. M.; Patel, R.; Ghosh, K. Significant enhancement of optical absorption through nano-structuring of copper based oxide semiconductors: possible future materials for solar energy applications. Phys. Chem. Chem. Phys. 2014, 16 (22), 11054-11066.

(28) Dubale, A. A.; Su, W.-N.; Tamirat, A. G.; Pan, C.-J.; Aragaw, B. A.; Chen, H.-M.; Chen, C.-H.; Hwang, B.-J. The synergetic effect of graphene on $\mathrm{Cu} 2 \mathrm{O}$ nanowire arrays as a highly efficient hydrogen evolution photocathode in water splitting. J. Mater. Chem. A 2014, 2 (43), 18383-18397.

(29) Dubale, A. A.; Pan, C.-J.; Tamirat, A. G.; Chen, H.-M.; Su, W.N.; Chen, C.-H.; Rick, J.; Ayele, D. W.; Aragaw, B. A.; Lee, J.-F.; Yang, Y.-W.; Hwang, B.-J. Heterostructured $\mathrm{Cu} 2 \mathrm{O} / \mathrm{CuO}$ decorated with nickel as a highly efficient photocathode for photoelectrochemical water reduction. J. Mater. Chem. A 2015, 3 (23), 12482-12499.

(30) Dubale, A. A.; Tamirat, A. G.; Chen, H.-M.; Berhe, T. A.; Pan, C.-J.; Su, W.-N.; Hwang, B.-J. A highly stable $\mathrm{CuS}$ and $\mathrm{CuS}-\mathrm{Pt}$ modified $\mathrm{Cu} 2 \mathrm{O} / \mathrm{CuO}$ heterostructure as an efficient photocathode for the hydrogen evolution reaction. J. Mater. Chem. A 2016, 4 (6), 2205-2216.

(31) Yang, Y.; Xu, D.; Wu, Q.; Diao, P. Cu2O/CuO Bilayered Composite as a High-Efficiency Photocathode for Photoelectrochemical Hydrogen Evolution Reaction. Sci. Rep. 2016, 6, 35158.

(32) Septina, W.; Prabhakar, R. R.; Wick, R.; Moehl, T.; Tilley, S. D. Stabilized Solar Hydrogen Production with $\mathrm{CuO} / \mathrm{CdS}$ Heterojunction Thin Film Photocathodes. Chem. Mater. 2017, 29 (4), 17351743.

(33) Zhang, L.; Jing, D.; Guo, L.; Yao, X. In Situ Photochemical Synthesis of Zn-Doped Cu2O Hollow Microcubes for High Efficient Photocatalytic H2 Production. ACS Sustainable Chem. Eng. 2014, 2 (6), $1446-1452$.

(34) Zhang, W.; Yang, X.; Zhu, Q.; Wang, K.; Lu, J.; Chen, M.; Yang, Z. One-Pot Room Temperature Synthesis of $\mathrm{Cu} 2 \mathrm{O} / \mathrm{Ag}$ Composite Nanospheres with Enhanced Visible-Light-Driven Photocatalytic Performance. Ind. Eng. Chem. Res. 2014, 53 (42), 1631616323.

(35) Li, Z.; Zhang, Z. Tetrafunctional Cu2S thin layers on $\mathrm{Cu} 2 \mathrm{O}$ nanowires for efficient photoelectrochemical water splitting. Nano Res. 2018, 11 (3), 1530-1540.

(36) Zhang, Z.; Dua, R.; Zhang, L.; Zhu, H.; Zhang, H.; Wang, P. Carbon-Layer-Protected Cuprous Oxide Nanowire Arrays for Efficient Water Reduction. ACS Nano 2013, 7 (2), 1709-1717.

(37) Emin, S.; Abdi, F. F.; Fanetti, M.; Peng, W.; Smith, W.; Sivula, K.; Dam, B.; Valant, M. A novel approach for the preparation of textured $\mathrm{CuO}$ thin films from electrodeposited $\mathrm{CuCl}$ and $\mathrm{CuBr}$. J. Electroanal. Chem. 2014, 717-718, 243-249.

(38) Jang, Y. J.; Jang, J.-W.; Choi, S. H.; Kim, J. Y.; Kim, J. H.; Youn, D. H.; Kim, W. Y.; Han, S.; Sung Lee, J. Tree branch-shaped cupric oxide for highly effective photoelectrochemical water reduction. Nanoscale 2015, 7 (17), 7624-7631.

(39) Chen, D.; Liu, Z. Dual-Axial Gradient Doping (Zr and Sn) on Hematite for Promoting Charge Separation in Photoelectrochemical Water Splitting. ChemSusChem 2018, 11 (19), 3438-3448.

(40) Li, Y.; Liu, Z.; Zhang, J.; Guo, Z.; Xin, Y.; Zhao, L. 1D/0D WO3/CdS heterojunction photoanodes modified with dual cocatalysts for efficient photoelectrochemical water splitting. J. Alloys Compd. 2019, 790, 493-501.

(41) Liu, Z.; Lu, X.; Chen, D. Photoelectrochemical Water Splitting of CuInS2 Photocathode Collaborative Modified with Separated Catalysts Based on Efficient Photogenerated Electron-Hole Separation. ACS Sustainable Chem. Eng. 2018, 6 (8), 10289-10294.
(42) Tilley, S. D.; Schreier, M.; Azevedo, J.; Stefik, M.; Graetzel, M. Ruthenium Oxide Hydrogen Evolution Catalysis on Composite Cuprous Oxide Water-Splitting Photocathodes. Adv. Funct. Mater. 2014, 24 (3), 303-311.

(43) Bornoz, P.; Abdi, F. F.; Tilley, S. D.; Dam, B.; van de Krol, R.; Graetzel, M.; Sivula, K. A Bismuth Vanadate-Cuprous Oxide Tandem Cell for Overall Solar Water Splitting. J. Phys. Chem. C 2014, 118 (30), 16959-16966.

(44) Morales-Guio, C. G.; Liardet, L.; Mayer, M. T.; Tilley, S. D.; Grätzel, M.; Hu, X. Photoelectrochemical Hydrogen Production in Alkaline Solutions Using $\mathrm{Cu} 2 \mathrm{O}$ Coated with Earth-Abundant Hydrogen Evolution Catalysts. Angew. Chem., Int. Ed. 2014, 54 (2), 664-667.

(45) Chen, D.; Liu, Z.; Guo, Z.; Yan, W.; Xin, Y. Enhancing light harvesting and charge separation of $\mathrm{Cu} 2 \mathrm{O}$ photocathodes with spatially separated noble-metal cocatalysts towards highly efficient water splitting. J. Mater. Chem. A 2018, 6 (41), 20393-20401.

(46) Lan, Y.; Liu, Z.; Guo, Z.; Li, X.; Zhao, L.; Zhan, L.; Zhang, M. A $\mathrm{ZnO} / \mathrm{ZnFe} 2 \mathrm{O} 4$ uniform core-shell heterojunction with a tubular structure modified by $\mathrm{NiOOH}$ for efficient photoelectrochemical water splitting. Dalton Transactions 2018, 47 (35), 12181-12187.

(47) Luo, J.; Steier, L.; Son, M.-K.; Schreier, M.; Mayer, M. T.; Grätzel, M. Cu2O Nanowire Photocathodes for Efficient and Durable Solar Water Splitting. Nano Lett. 2016, 16 (3), 1848-1857.

(48) Pan, L.; Kim, J. H.; Mayer, M. T.; Son, M.-K.; Ummadisingu, A.; Lee, J. S.; Hagfeldt, A.; Luo, J.; Grätzel, M. Boosting the performance of $\mathrm{Cu} 2 \mathrm{O}$ photocathodes for unassisted solar water splitting devices. Nat. Catal. 2018, 1 (6), 412-420.

(49) Hou, J.; Yang, C.; Cheng, H.; Jiao, S.; Takeda, O.; Zhu, H. High-performance $\mathrm{p}-\mathrm{Cu} 2 \mathrm{O} / \mathrm{n}-\mathrm{TaON}$ heterojunction nanorod photoanodes passivated with an ultrathin carbon sheath for photoelectrochemical water splitting. Energy Environ. Sci. 2014, 7 (11), $3758-3768$

(50) Shi, W.; Zhang, X.; Li, S.; Zhang, B.; Wang, M.; Shen, Y. Carbon coated $\mathrm{Cu} 2 \mathrm{O}$ nanowires for photo-electrochemical water splitting with enhanced activity. Appl. Surf. Sci. 2015, 358, 404-411.

(51) Kecsenovity, E.; Endrodi, B.; Tóth, P. S.; Zou, Y.; Dryfe, R. A. W.; Rajeshwar, K.; Janáky, C. Enhanced Photoelectrochemical Performance of Cuprous Oxide/Graphene Nanohybrids. J. Am. Chem. Soc. 2017, 139 (19), 6682-6692.

(52) Tran, P. D.; Batabyal, S. K.; Pramana, S. S.; Barber, J.; Wong, L. H.; Loo, S. C. J. A cuprous oxide-reduced graphene oxide (Cu2OrGO) composite photocatalyst for hydrogen generation: employing rGO as an electron acceptor to enhance the photocatalytic activity and stability of Cu2O. Nanoscale 2012, 4 (13), 3875-3878.

(53) Xu, X.; Liu, Y.; Zhu, Y.; Fan, X.; Li, Y.; Zhang, F.; Zhang, G.; Peng, W. Fabrication of a Cu2O/g-C3N4/WS2 Triple-Layer Photocathode for Photoelectrochemical Hydrogen Evolution. ChemElectroChem 2017, 4 (6), 1498-1502.

(54) Frackowiak, E.; Béguin, F. Carbon materials for the electrochemical storage of energy in capacitors. Carbon 2001, 39 (6), 937-950.

(55) Devarapalli, R. R.; Szunerits, S.; Coffinier, Y.; Shelke, M. V.; Boukherroub, R. Glucose-Derived Porous Carbon-Coated Silicon Nanowires as Efficient Electrodes for Aqueous Micro-Supercapacitors. ACS Appl. Mater. Interfaces 2016, 8 (7), 4298-4302.

(56) Yu, L.; Li, G.; Zhang, X.; Ba, X.; Shi, G.; Li, Y.; Wong, P. K.; Yu, J. C.; Yu, Y. Enhanced Activity and Stability of Carbon-Decorated Cuprous Oxide Mesoporous Nanorods for $\mathrm{CO} 2$ Reduction in Artificial Photosynthesis. ACS Catal. 2016, 6 (10), 6444-6454.

(57) Paracchino, A.; Mathews, N.; Hisatomi, T.; Stefik, M.; Tilley, S. D.; Grätzel, M. Ultrathin films on copper(i) oxide water splitting photocathodes: a study on performance and stability. Energy Environ. Sci. 2012, 5 (9), 8673-8681.

(58) Golden, T. D.; Shumsky, M. G.; Zhou, Y.; VanderWerf, R. A.; Van Leeuwen, R. A.; Switzer, J. A. Electrochemical Deposition of Copper(I) Oxide Films. Chem. Mater. 1996, 8 (10), 2499-2504. 
(59) de Jongh, P. E.; Vanmaekelbergh, D.; Kelly, J. J. Cu2O: Electrodeposition and Characterization. Chem. Mater. 1999, 11 (12), 3512-3517.

(60) Rahal, H.; Kihal, R.; Affoune, A. M.; Rahal, S. Electrodeposition and characterization of $\mathrm{Cu} 2 \mathrm{O}$ thin films using sodium thiosulfate as an additive for photovoltaic solar cells. Chin. J. Chem. Eng. 2018, 26 (2), 421-427.

(61) Akimoto, K.; Ishizuka, S.; Yanagita, M.; Nawa, Y.; Paul, G. K.; Sakurai, T. Thin film deposition of $\mathrm{Cu} 2 \mathrm{O}$ and application for solar cells. Sol. Energy 2006, 80 (6), 715-722.

(62) Mahalingam, T.; Chitra, J. S. P.; Rajendran, S.; Sebastian, P. J. Potentiostatic deposition and characterization of $\mathrm{Cu} 2 \mathrm{O}$ thin films. Semicond. Sci. Technol. 2002, 17 (6), 565.

(63) Schmidt-Whitley, R. D.; Martinez-Clemente, M.; Revcolevschi, A. Growth and microstructural control of single crystal cuprous oxide Cu2O. J. Cryst. Growth 1974, 23 (2), 113-120.

(64) Li, L.; Li, G.; Xu, J.; Zheng, J.; Tong, W.; Hu, W. Insights into the roles of organic coating in tuning the defect chemistry of monodisperse $\mathrm{TiO} 2$ nanocrystals for tailored properties. Phys. Chem. Chem. Phys. 2010, 12 (36), 10857-10864.

(65) Zhang, Y.; Zhang, N.; Tang, Z.-R.; Xu, Y.-J. Graphene Transforms Wide Band Gap ZnS to a Visible Light Photocatalyst. The New Role of Graphene as a Macromolecular Photosensitizer. ACS Nano 2012, 6 (11), 9777-9789.

(66) Fang, J.; Xuan, Y. Investigation of optical absorption and photothermal conversion characteristics of binary $\mathrm{CuO} / \mathrm{ZnO}$ nanofluids. RSC Adv. 2017, 7 (88), 56023-56033.

(67) Qi, H.; Wolfe, J.; Fichou, D.; Chen, Z. Cu2O Photocathode for Low Bias Photoelectrochemical Water Splitting Enabled by NiFeLayered Double Hydroxide Co-Catalyst. Sci. Rep. 2016, 6, 30882.

(68) Toe, C. Y.; Zheng, Z.; Wu, H.; Scott, J.; Amal, R.; Ng, Y. H. Photocorrosion of Cuprous Oxide in Hydrogen Production: Rationalising Self-Oxidation or Self-Reduction. Angew. Chem., Int. Ed. 2018, 57 (41), 13613-13617.

(69) Toe, C. Y.; Scott, J.; Amal, R.; Ng, Y. H. Recent advances in suppressing the photocorrosion of cuprous oxide for photocatalytic and photoelectrochemical energy conversion. J. Photochem. Photobiol., C 2019, 40, 191.

(70) Shi, H.; Chen, G.; Zhang, C.; Zou, Z. Polymeric g-C3N4 Coupled with $\mathrm{NaNbO} 3$ Nanowires toward Enhanced Photocatalytic Reduction of CO2 into Renewable Fuel. ACS Catal. 2014, 4 (10), 3637-3643.

(71) Han, X.; Xu, D.; An, L.; Hou, C.; Li, Y.; Zhang, Q.; Wang, H. Ni-Mo nanoparticles as co-catalyst for drastically enhanced photocatalytic hydrogen production activity over g-C3N4. Appl. Catal., B 2019, 243, 136-144.

(72) Bandosz, T. J.; Ania, C. O. Origin and Perspectives of the Photochemical Activity of Nanoporous Carbons. Adv. Sci. 2018, 5 (9), 1800293.

(73) Murphy, D. M.; Cullen, R. J.; Jayasundara, D. R.; Doyle, R. L.; Lyons, M. E. G.; Colavita, P. E. Heterogeneous Charge Transfer at the Amorphous Carbon/Solution Interface: Effect on the Spontaneous Attachment of Aryldiazonium Salts. J. Phys. Chem. C 2013, 117 (44), 22768-22777.

(74) Miyajima, Y.; Tison, Y.; Giusca, C. E.; Stolojan, V.; Watanabe, H.; Habuchi, H.; Henley, S. J.; Shannon, J. M.; Silva, S. R. P. Probing the band structure of hydrogen-free amorphous carbon and the effect of nitrogen incorporation. Carbon 2011, 49 (15), 5229-5238. 